\title{
Unique Hydration Caves and Recommended Photogrammetric Methods for Their Documentation
}

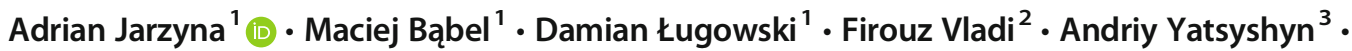 \\ Danuta Olszewska-Nejbert ${ }^{1} \cdot$ Krzysztof Nejbert $^{1} \cdot$ Andriy Bogucki $^{3}$
}

Received: 6 March 2019 / Accepted: 7 January 2020 / Published online: 14 February 2020

(C) The Author(s) 2020

\begin{abstract}
Active anhydrite hydration during weathering leading to crystallisation of secondary gypsum and significant volume expansion was investigated and documented by the authors at three sites: the environs of Walkenried (Germany), Dingwall (Canada), and Pisky (Ukraine). As a result of these processes, peculiar landscape forms were created: hydration domes and ridges with empty internal chambers, some of them large enough to be called hydration caves (German: Quellungshöhlen). Currently, there are only four recognised sites on Earth featuring such a unique landscape and with a large group of hydration caves in one place (the fourth site is in the Alebastrovyye Islands, Russia). These sites constitute a particularly valuable geological and geomorphological heritage, including potential geosites and geomorphosites which require special protection. Actively growing hydration domes and caves change shape and size within a short time span, on the scale of months, years, or decades. Their study and proper protection require these changes to be monitored. Several different methods of documentation were applied in the field in order to document continuing morphological changes. The practical aspects of the use of each of these methods were assessed, demonstrating that the photogrammetric methods offer the greatest utility; not only are they the most efficient (fast and sufficiently precise) but also, compared with other methods, they yielded the most complete results. The key documentation of outcrops in Canada and Ukraine was executed with the application of terrestrial photogrammetry at Pisky (GoPro camera) and aerial photogrammetry at Dingwall (unmanned aerial vehicle). Application of these methods enabled the recording of the morphology associated with the hydration process in the form of $2.5 \mathrm{D}$ and $3 \mathrm{D}$ models as well as of orthophotomaps. The maps and the models were created using the Photoscan programme. The authors demonstrate that the photogrammetric models can be used for spatial morphological analysis of hydration forms in the ArcGIS programme. Repetition of this documentation in future will enable analysis of the morphological changes expected to occur during the progressive expansive hydration of anhydrite.
\end{abstract}

Keywords Hydration · Anhydrite $\cdot$ Cave $\cdot$ Quellungshöhlen $\cdot$ Geomorphology $\cdot$ Photogrammetry

This article is part of the Topical Collection on Geoheritage and Conservation: Modern Approaches and Applications Towards the 2030 Agenda, IX ProGEO Symposium, Poland, 25-28th June, 2018

\author{
Adrian Jarzyna \\ a.jarzyna@student.uw.edu.pl \\ $\triangle$ Maciej Bąbel \\ m.babel@uw.edu.pl \\ Damian Ługowski \\ lugowski.damian@gmail.com \\ Firouz Vladi \\ fvladi@t-online.de \\ Andriy Yatsyshyn \\ jacyshyn@yahoo.com \\ Danuta Olszewska-Nejbert \\ don@uw.edu.pl
}

Krzysztof Nejbert

knejbert@uw.edu.pl

Andriy Bogucki

pleistocene@ukr.net

1 Faculty of Geology, University of Warsaw, A1. Żwirki i Wigury 93, PL-02-089 Warsaw, Poland

2 Deutsches Gipsmuseum und Karstwanderweg e.V, Düna 9a, D-37520 Osterode, Germany

3 Faculty of Geography, Ivan-Franko National University of Lviv, Doroshenka 41, Lviv 79000, Ukraine 


\section{Introduction}

Hydration of the mineral anhydrite (chemical formula: $\mathrm{CaSO}_{4}$ ) is a common process observed in many places on Earth. Most often, exposed anhydrite rocks are subjected to hydration in the weathering zone under the influence of meteoric waters. As a result of this process, a secondary mineral, gypsum $\left(\mathrm{CaSO}_{4} \cdot 2 \mathrm{H}_{2} \mathrm{O}\right)$, crystallises according to the reaction $\mathrm{CaSO}_{4}+2 \mathrm{H}_{2} \mathrm{O} \rightarrow \mathrm{CaSO}_{4} \cdot 2 \mathrm{H}_{2} \mathrm{O}$. It is known that this reaction and the growth of gypsum crystals can lead to significant volume expansion: theoretically, up to $62.6 \%$ in an open system (Zanbak and Arthur 1986; Reimann 1991). Actually, in many cases, no volume expansion is observed or expansion is too small or too slow to be detected. However, there are relatively rare examples where volume expansion is more rapid and results in dramatic deformational structures and forms.

Remarkable expansion commonly takes place when buried anhydrite rocks are rapidly subjected to contact with a large amount of fresh water, e.g. during the construction of tunnels or road cuts, or in excavations such as quarries, pits, or other sites (Alonso et al. 2013). Expansion in tunnels cut through anhydrite formations promotes the narrowing and closure of the tunnel openings. This is particularly troublesome, e.g. in Western Europe (Butscher et al. 2016), necessitating repair work which is usually very expensive because, as a rule, the expansion continues for many years and is difficult and, in practice, impossible to stop (sometimes continuing until all of the anhydrite is hydrated). Even more costly and destructive are recently recorded uplifts of the surface of the ground and associated damage to houses, roads, and other infrastructure elements in several towns in Europe (Staufen im Breisgau, Böblingen, and Rudersberg in Germany, Lochwiller in France) where improper installation of heat pumps has disturbed the hydrological system in the subsurface (Fleuchaus and Blum 2017, with references). This has led to large-scale hydration of anhydrite formations below the surface and catastrophic volume expansion.

Despite many years of studies, the processes of expansive hydration of anhydrite are insufficiently understood and still difficult to predict. The abovementioned examples clearly indicate that studies of these problems are very important, not only for 'pure' science but also for practical reasons.

The discussed hydration of anhydrite also promotes smaller-scale but spectacular geomorphological effects: 'pressure blisters' and 'pressure ridges' appearing directly on the surfaces of rocks. The creation of these forms is related to stress exerted by secondary gypsum, which crystallises at the expense of anhydrite in the outermost zone of the weathering rock (Reimann 1991; Butscher et al. 2016). Stress is released in the upper part of the anhydrite weathering zone in places where the expanding surface layer of the rock detaches from the substrate and rises. Empty chambers appear inside the domes and ridges and become enlarged along with uplift of the surface layer and growth of the domes (driven by anhydrite hydration processes). Some chambers may reach sizes large enough to permit a man to crawl inside, and thus constitute caves; some caves have grown large enough to shelter a group of standing people (Stolberg 1926). Such rare caves have been known since the eighteenth century in the environs of the Harz Mts. in Germany (Behrens 1703). Caves of this type, which have also been identified in the USA, were called hydration caves by Kraus (1905), as well as Quellungshöhlen (German), translated into English as 'swelling caves', by Biese (1931) (e.g. Bögli 1980).

The described hydration domes, chambers, and caves are also known by many other names, such as bulge caves, gypsum bubbles, pressure blisters, and expansion blisters. It is important not to confuse the hydration domes and caves discussed here with the so-called gypsum tumuli (singular: tumulus), which are morphologically similar forms appearing exclusively on the surface of weathering gypsum rocks (Calaforra and Pulido-Bosch 1999). The origin of the latter has no connection with hydration. It is believed that gypsum tumuli are formed due to cyclic wetting and drying of insolated bare gypsum rocks in a semi-dry climate or microclimate (Calaforra and Pulido-Bosch 1999).

Hydration caves and associated forms are 'living', fragile, and ephemeral objects. They can develop and be destroyed rapidly within a period as brief as several years (as observed at the Pisky quarry in Ukraine, where one hydration cave appeared and grew to a height of $1.3 \mathrm{~m}$ in a period of several years; Fig. 2e; Bąbel et al. 2017b, Fig. 1). Other caves grow more slowly, commonly at a rate less than a few millimetres per year (Reimann and Vladi 2003; the authors' own observations).

All these caves are at risk of collapse, since their roof bed is weakly supported, insufficiently thick, and subject to increasingly intense weathering along with their uplifts. For example, one of the largest hydration caves, known as Forest Forge (German: Waldschmiede), in the Harz Mts. in Germany developed and existed for several decades but collapsed in 1966 (Reinboth 1997). Furthermore, hydration domes are composed of gypsum and anhydrite, which are subject to more rapid karst dissolution than in the case of carbonate rocks. Due to rains as well as melting of the snow cover, spectacular karren commonly develop on the rocky surfaces of the discussed forms (e.g. Stenson and Ford 1993).

Actively growing hydration caves change shape and size within a short time span. Their study and proper protection requires these changes to be monitored. It is only through frequent documentation that the morphological evolution of these forms can be traced and their appearance and existence saved from oblivion. For example, it is only thanks to 


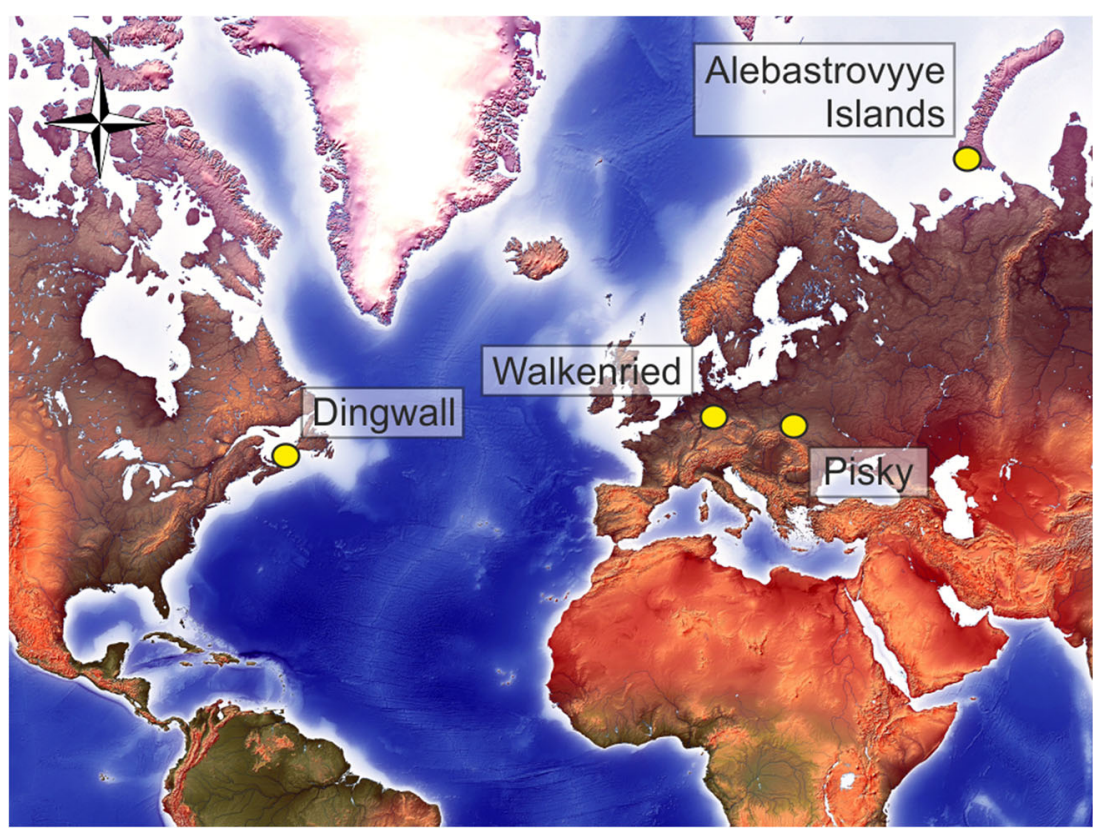

Fig. 1 Location of the main sites with actively growing hydration caves in the world (source: http://www.naturalearthdata.com/downloads/)

drawings, photographic documentation, and some measurements and descriptions that we know what the abovementioned Waldschmiede looked like and how it evolved until its collapse.

Recently, several more advanced methods have been tested and used for documentation and monitoring of anhydrite hydration relief by the authors of the present paper in Ukraine and Canada. Among them, photogrammetric methods were acknowledged as particularly useful.

The main aims of the present paper are 1) to characterise selected features of some rare (and, in some cases, littleknown) sites with currently developing hydration caves in order to draw attention to these unique and fragile objects, which represent a geological and geomorphological heritage worthy of special protection, including potential geosites and geomorphosites, and 2) to present and recommend the most efficient photogrammetric methods for their field documentation, useful for monitoring their morphological evolution based on the authors' own experience, gained in the course of studying three sites: Walkenried in Germany, Pisky in Ukraine, and Dingwall in Canada.

\section{Occurrence of Hydration Caves}

Hydration domes with both small and large chambers (caves) have been described in only several countries, including Germany, the USA, Russia, Canada, and Ukraine (Figs. 1 and 2; Kraus 1905; Yushkin 1994; Reimann and Vladi 2003; Babel et al. 2007, 2017a). Other recorded occurrences, e.g. in the countries of middle Asia (Kes 1961), require confirmation by means of reliable petrographic data, as they may represent gypsum tumuli.

The number of hydration caves that can be identified depends on the definition of the term cave. According to the most commonly accepted definition, 'a cave is a natural underground opening in rock that is large enough for human entry' (Ford and Williams 2007, p. 209). Accordingly, it is the size of a human being which determines which hydration chambers are really caves (Bögli 1980). The smaller the person, the greater the number of hydration caves that can be distinguished. Currently there are only about fifty described objects which can be considered hydration caves. Among the occurrences recorded to date, only four sites can be treated as large (Fig. 1):

1) the area of the Sachsenstein, Blumenberg, and Höllstein hills, between Walkenried and Bad Sachsa, southern margin of the Harz Mts. in Germany (Fig. 2g-i; Stolberg 1926; Biese 1931; Reimann 1991; Reinboth 1997);

2) the Alebastrovyye Islands in the Kostin Shar strait, in Novaya Zemlya, Russia (Yushkin 1994);

3) an abandoned gypsum quarry at Dingwall in Nova Scotia, Canada (Fig. 2a-c; Beales and Oldershaw 1969; Stenson 1990; Reimann and Vladi 2003);

4) a gypsum quarry at Pisky, near Lviv, in Western Ukraine (Fig. 2d-f; Bąbel et al. 2007, 2017a, b).

At all of these sites, hydration domes and caves occur in a large number of forms within a relatively small area (maximum: several $\mathrm{km}^{2}$ ), and anhydrite hydration processes are particularly active. 

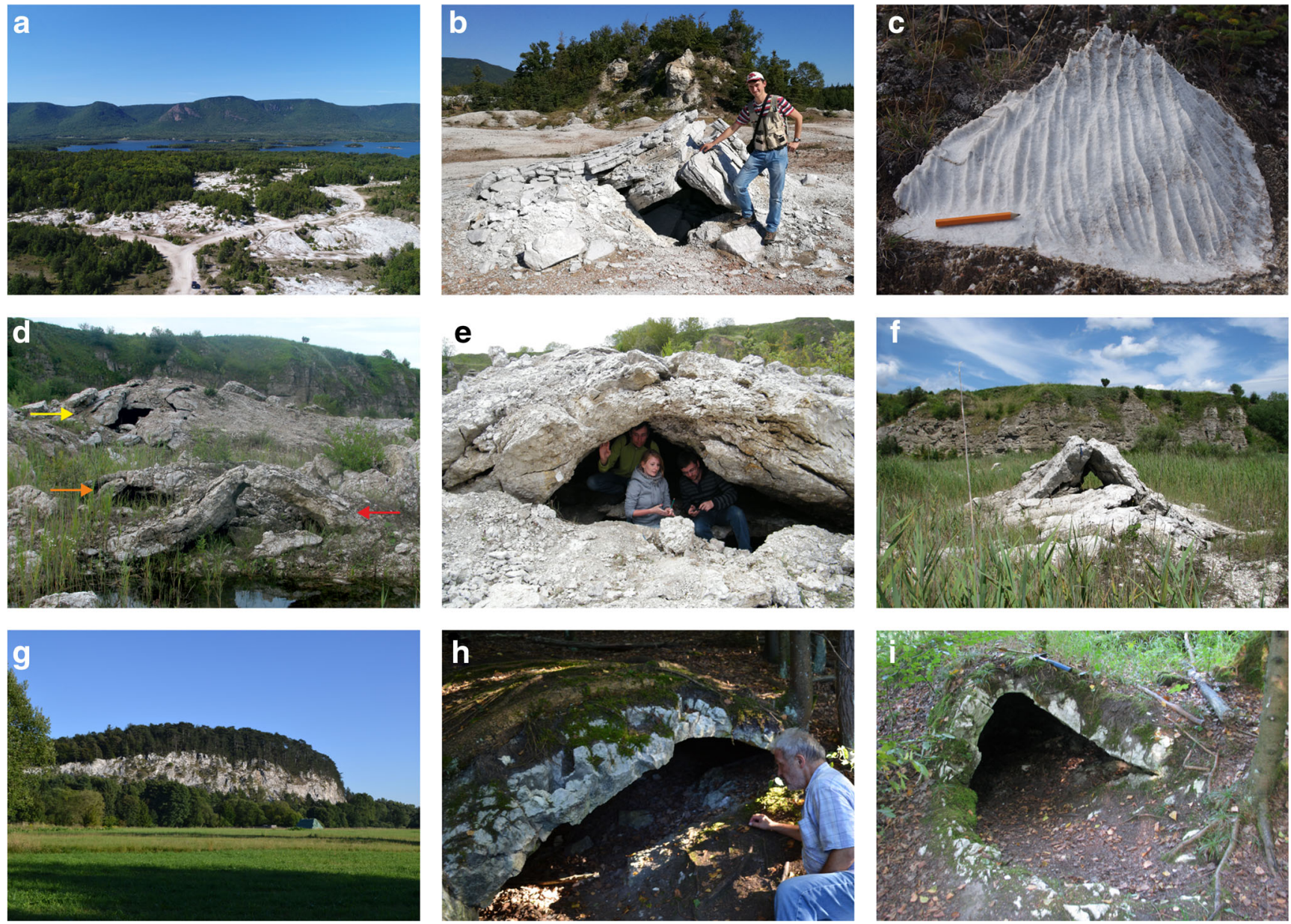

Fig. 2 Representative pictures of the anhydrite weathering sites studied by the authors: Dingwall in Canada $(\mathbf{a}, \mathbf{b}, \mathbf{c})$, Pisky in Ukraine $(\mathbf{d}, \mathbf{e}, \mathbf{f})$, and the environs of Walkenried in Germany $(\mathbf{g}, \mathbf{h}, \mathbf{i})$. a View of the Dingwall gypsum quarry, with the Aspy River estuary and Cape Breton Highlands in the background (date of photo: 15 September 2018). b Hydration cave exhibiting tepee structure (in the photo: A. Jarzyna; date of photo: 13 September 2018). c Exemplary gypsum-anhydrite block with karst solution relief; rillenkarren passing down into a flat ausgleichsfläche (with a pencil lying on it; see Bögli 1980, fig. 3.3 for explanation of these terms; date of photo: 21 September 2018). d Three hydration forms at the bottom of Pisky quarry: the so-called Great Dome

\section{Walkenried}

Hydration caves (Quellungshöhlen) develop in a zone of weathering of Permian (Zechstein) anhydrites on the gypsum-anhydrite plateau between Walkenried and Bad Sachsa, bordered on the west by a picturesque rocky cliff over the Uffe River (Fig. 2g). The anhydrites represent the earliest Werra (Z1) cyclothem and were deposited in the giant evaporite Zechstein Basin of Central Europe. The peculiar hydration relief is hidden by the forest covering the Sachsenstein, Blumenberg, and Höllstein hills (Reimann 1991; Reinboth 1997). Hydration domes and caves (known in earlier times by local inhabitants as 'dwarf holes', German: ZwergLöchern; Behrens 1703) crop out in several places (Fig. 2h with the entrance to the largest hydration cave at Pisky (yellow arrow) and forms nos. 94 (red arrow) and 95 (orange arrow; date of photo: 6 July 2013). e The entrance to a rapidly growing hydration cave within form no. 42 (see Fig. 3b; in the photo, from right, D. Ługowski, M. Madej, and I. Szczepańska, date of the photo: 4 May 2014). f The socalled Great Tepee hydration cave (date of photo: 31 July 2016). g The gypsum-anhydrite cliff of the Sachsenstein hill east of Walkenried (date of photo: 24 August 2016). $\mathbf{h}$ The hydration cave called Zwergenhäuslein (see Reinboth 1997), investigated by F. Vladi (date of photo: 24 August 2016). i The hydration cave called Diamantenloch; see Reinboth 1997 (date of photo: 24 August 2016)

and i) scattered within an area of several $\mathrm{km}^{2}$. The abovementioned Waldschmiede was the largest cave, with a circular floor 7.5-8.0 $\mathrm{m}$ in diameter and a height of about $2 \mathrm{~m}$ (Stolberg 1926). Other remarkable extant caves include the so-called Zwergenkirche (Dwarf Church) cave, which is about $1.2 \mathrm{~m}$ in height.

\section{Alebastrovyye Islands}

Numerous hydration domes occur on one of the islands, which is only 800-m long and 150-m wide and composed entirely of Lower Carboniferous (Serpukhovian) anhydrites covered by a weathering gypsum cap 1.5-3.0-m thick (Yushkin 1994). The 
bases of the domes reach up to $10 \times 15 \mathrm{~m}$ in size; the domes are $0.5-1.5-\mathrm{m}$ high. The empty chambers (hydration caves) inside the domes attain $1.5 \mathrm{~m}$ in height.

\section{Dingwall}

Dingwall is located in Eastern Canada, in the northern part of the province of Nova Scotia, within the northernmost part of Cape Breton Island, in an area where expansive hydration of anhydrite has been frequently recorded (Stenson 1990; Ford and Williams 2007). The site with hydration caves is in an abandoned gypsum quarry located west of the main buildings of Dingwall and east of Cape North (Figs. 2a and 3c).

The anhydrite rocks subjected to weathering at Dingwall are Lower Carboniferous (Mississippian) in age and represent cycle 1A within the Windsor Group (Moore and Ryan 1976; Adams 1991). The evaporites and accompanying carbonate rocks were deposited in the Maritimes Basin between ca 344 and $330 \mathrm{Ma}$ (MacNeil et al. 2018).

The quarry was abandoned in 1955; since then, its anhydrite floor has been subjected to intensive weathering. Within a short time following abandonment, spectacular karren forms developed on the surfaces of rocks (Stenson and Ford 1993). Hydration domes with empty hydration chambers and pressure ridges were observed on the floor of the quarry as early as 20 years following abandonment by Beales and Oldershaw (1969). In 1989, Stenson (1990) documented sixty-nine hydration forms. Spectacular hydration caves were recorded in 1996 by one of the authors (F.V.) of the present paper; since then, they have been monitored once every few years. The latest data was collected during an expedition in September 2018. The results of this expedition, i.e. measurements and photogrammetric documentation, have been elaborated.

Spectacular hydration relief is most developed in three distinct separate zones in the quarry: the western, central, and eastern zones (Fig. 3c). Hydration forms include hydration domes, both with empty chambers and with hydration caves inside, and hydration ridges. According to the collected data, at least seventy hydration domes with hydration chambers and caves are currently visible in these zones (Fig. 2b).

One of the largest hydration caves documented to date was the so-called Maruhn Cave, with a floor $9.5 \times 4.5 \mathrm{~m}$ and a height of approximately $1 \mathrm{~m}$, measured in 2003 (Reimann and Vladi 2003). Unfortunately, the roof of this cave had collapsed by 2017. Meanwhile, the Ramesh Cave, reaching an even greater size, had been discovered. According to measurements in 2008, its floor measured $10.7 \times 6.6 \mathrm{~m}$ and its height reached $1.10 \mathrm{~m}$. The height of this actively growing cave had increased to $1.32 \mathrm{~m}$ and the floor size had decreased to $9.95 \times 4.10 \mathrm{~m}$ by October 2017 . According to documentation, in September 2018, the floor of the Ramesh Cave was $8.87 \times 2.97 \mathrm{~m}$, with a height of $1.35 \mathrm{~m}$.

\section{Pisky}

The site at Pisky is located in Western Ukraine (Lviv Oblast), $25 \mathrm{~km}$ south of Lviv, and has been methodically studied by the authors and other researchers since 2012 (Lugowski et al. 2016). The nearest small town, Shchyrets', is located about $2.8 \mathrm{~km}$ north-west of the quarry at Pisky. The quarry is elongated along the WNW-ESE direction; a single outcrop of gypsum-anhydrite rocks is located at the bottom (Fig. 3a).

Evaporite rocks at Pisky quarry represent the so-called Badenian Salinity Crisis in the Central Paratethys and were deposited in the earliest Serravallian within the Carpathian Foredeep Basin (de Leeuw et al. 2018, with references). The rock, due to having been subjected to weathering, is composed of snow-white fine-grained anhydrite and gypsum.

Hydration forms include both domes with chambers and caves and pressure ridges. Approximately 100 domal forms have been recorded there, with 25 of them representing hydration caves, including several rock shelters, natural bridges, and rock arches (see Fig. 2d). The largest identified actively growing hydration cave was found inside the so-called Great Dome (Fig. 2d). The cave's maximum dimensions were $9.5 \times$ $7.8 \mathrm{~m}$, with a height of approximately $1.2 \mathrm{~m}$, in August 2016 (Babel et al. 2017a). This cave was destroyed in winter 2016/ 17 during quarrying operations.

The site at Pisky is in danger of destruction due to its location within an active gypsum quarry (Bogucki and Tomeniuk 2016). Due to excavations in 2016/2017, about $50 \%$ of the hydration domes and 14 identified hydration caves were destroyed. The destroyed objects including some of the largest hydration caves, however, had been well documented (e.g. Figure $2 \mathrm{~d}$ and e) prior to their destruction; this documentation permits their analysis and further study.

\section{Listed Localities as Potential Geosites and Geomorphosites}

The areas and morphological objects listed above show features which enable their consideration as potential geosites and geomorphosites (according to the definitions of these terms as currently discussed; see Reynard 2009; Brilha 2018, with references). These sites exhibit exceptionally high geological and geomorphological values and represent a true natural curiosity. The active increase in the volume of the weathering anhydrite rocks currently in progress at these sites is a rarely recorded phenomenon. The rapidity, scale, and form of this volume increase are all unique. The expansive hydration of anhydrite leads to peculiar structural transformations of the rocky substrate and the development of spectacular hydration landforms: domes, ridges, and subsurface caverns. These landforms include uncommon speleological objects, i.e. hydration caves; the largest such caves $(1.5 \mathrm{~m}$ in height and 


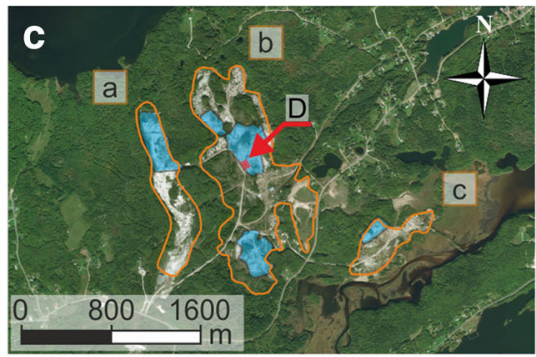

Legend

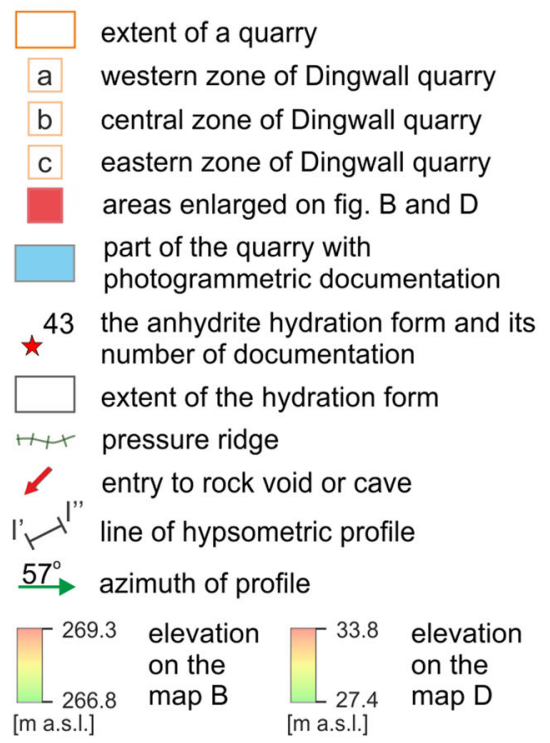
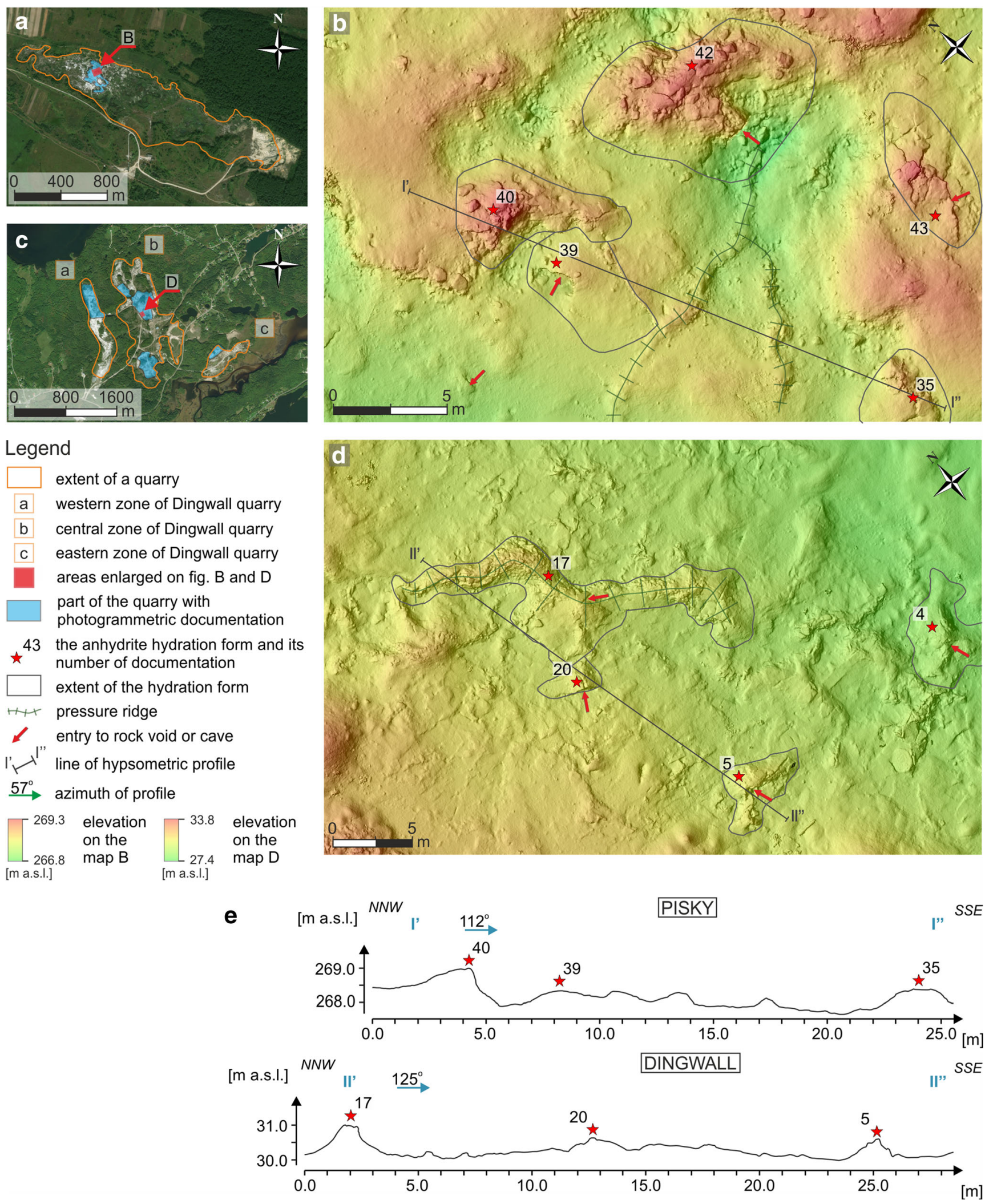

Fig. 3 Photogrammetric documentation of the morphology of the quarry at Pisky in Ukraine (a, b, c) and Dingwall in Canada (c, d, e). a, c The range of documented areas at Pisky (a) and Dingwall (c) on the satellite map (source of maps: the ArcGIS programme). b, d Selected DSM fragments of the study areas at Pisky (b) and Dingwall (d), with exemplary hydration domes and ridges. e Hypsometric profiles along the $\mathrm{I}^{\prime}-\mathrm{I}^{\prime \prime}$ and $\mathrm{II}^{\prime}-\mathrm{II}^{\prime \prime}$ lines along with the marked highest points of hydration forms 
higher) occur precisely at these sites. The sites also represent calcium sulphate karst with surfaces typical of karst relief, in particular spectacular gypsum-anhydrite karren. Each site also includes its own features, which are important from the point of view of regional geology, sedimentology, or historical geology. Perhaps the most valuable feature offered by the sites is the rare opportunity to study active hydration processes, which is important for a better understanding of similar catastrophic anhydrite hydration phenomena occurring in the deeper subsurface during excavations and various construction projects (Alonso et al. 2013; Butscher et al. 2016; Fleuchaus and Blum 2017). Proper protection is necessary to secure these sites for continued study in future. At present, only the hydration caves at Walkenried are situated within a protected area.

The sites are characterised by their potential for geotourism. The landscape can be considered aesthetically significant, mainly because of the spectacular sparkling snow-white colour of the naturally sculpted karstified gypsum-anhydrite rocks. The Harz area, Pisky, and Dingwall are all readily accessible, and the hydration caves from Walkenried are already a great attraction for tourists. The caves are described for the benefit of visitors in information boards installed near these unique forms, as well as promoted via internet. The Alebastrovyye Islands lie in a remote, desolate, and inaccessible Arctic area; therefore, the evolution of hydration relief at this site is natural and undisturbed as yet by human activity.

\section{Methods of Documentation}

The following methods were applied by the authors for the documentation and monitoring of hydration relief: 1) traditional geological field observations (notes, drawings, measurements, samples, etc.), 2) photographic documentation, 3) video film documentation, 4) the benchmark method, 5) 3D terrestrial laser scanning, 6) scanning with LED structured light, 7) terrestrial photogrammetry, 8) aerial photogrammetry, and 9) the method of modelling of $2.5 \mathrm{D}$ and $3 \mathrm{D}$ objects with the application of photogrammetry.

The first four methods, terrestrial photogrammetry, and modelling methods were used at all three studied sites (Pisky, Dingwall, Walkenried), although the application of photogrammetry at Walkenried was rather limited since the relief there is hidden by forest; $3 \mathrm{D}$ laser scanning and scanning with LED structured light methods were used only at Pisky, aerial photogrammetry only at Dingwall. The most complete sets of methods were applied at Pisky and Dingwall; the methods used at Pisky were previously described and discussed by Ługowski et al. (2016) and Bura and Janowski (2017). A comparison of the listed documentation methods according to several selected criteria (Tables 1 and 2) as well as the authors' practical experience indicate that photogrammetric methods are the best and most efficient, meeting all the criteria regarding various useful aspects and features of the analysed methods (Table 1) and yielding the most complete and, according to our experience, sufficiently precise data sets.

Traditional observational methods are crucial for the study of geological and environmental processes; however, they do not provide complete quantitative characteristics of the morphology and morphological changes in the weathering zone. Methods other than photogrammetry supply a more or less limited data set for monitoring morphological evolution (see Lugowski et al. 2016).

Anhydrite hydration is associated with irreversible morphological changes over time. Deformations within the area of gypsum-anhydrite rocks are complicated and require not only structural and petrographic but also topographical documentation. Through the application of photogrammetric methods, topographic documentation was obtained in the forms of an orthophotomap and a digital surface model (DSM; Westoby et al. 2012). The absence of plant cover on the surface of bare gypsum-anhydrite rocks makes DSM equivalent to a digital terrain model (DTM) over most of the studied area and particularly for the investigated hydration forms.

The topographic documentation required the use of both terrestrial and aerial photogrammetry; the former method was also used for documentation of hydration domes and caves and small-scale details of relief such as karren (Fig. 2c).

\section{Map of the Study Area}

Photogrammetric fieldwork at Pisky and Dingwall proceeded in different ways, depending on the available equipment (Table 2). At Pisky, terrestrial photogrammetry was carried out using a digital video camcorder, whereas at Dingwall, the aerial photogrammetric documentation was conducted with the use of an unmanned aerial vehicle (UAV; Table 3).

Fieldwork at Pisky was carried out with a GoPro Hero 4 camera (Table 3). The shutter was released remotely using a mobile application on a mobile phone via Wi-Fi technology connecting the camera with the phone. The dedicated application installed on the mobile phone included features enabling full control over camera operation and live photo previews. Photographs were taken from a height of about $4 \mathrm{~m}$ with a camera fixed on a pole (Lugowski et al. 2016). The photo survey was designed to obtain $55 \%$ overlap between adjacent photos, both along and between the edges of photos. The whole site was divided into several photographed fields (see Ługowski et al. 2016 for more details). A Leica Viva GS12 GPS receiver with real-time kinematic (RTK) corrections with an accuracy of 1-2 cm was used for measurements of ground 
Table 1 Comparison of the nine documentation methods applied at Pisky and Dingwall on the basis of selected seven criteria (for additional data characterising the analysed methods, see: Ługowski et al. 2016; Bura and Janowski 2017)

\begin{tabular}{|c|c|c|c|c|c|c|c|c|}
\hline & $\begin{array}{l}\text { Research } \\
\text { goals }\end{array}$ & \begin{tabular}{|c|} 
Qualitative \\
characteristic \\
of research \\
a)
\end{tabular} & $\begin{array}{l}\text { Quantitative } \\
\text { characteristic } \\
\text { of research } \\
\text { b) }\end{array}$ & $\begin{array}{l}\text { Equivalence } \\
\text { of method } \\
\text { c) }\end{array}$ & $\begin{array}{l}\text { Labour } \\
\text { consumption } \\
\text { d) }\end{array}$ & $\begin{array}{c}\text { Efficiency } \\
\text { of methods } \\
\text { e) }\end{array}$ & $\begin{array}{l}\text { Area of } \\
\text { reseach } \\
\text { f) }\end{array}$ & $\begin{array}{l}\text { Field } \\
\text { workers } \\
\text { g) }\end{array}$ \\
\hline $\begin{array}{l}\text { Traditional geological } \\
\text { field observations }\end{array}$ & $\begin{array}{c}\text { General description } \\
\text { of study area }\end{array}$ & \multicolumn{7}{|c|}{ It doesn't concern } \\
\hline \begin{tabular}{c|} 
Photographic \\
documentation
\end{tabular} & \multirow{8}{*}{$\begin{array}{l}\text { Documentation } \\
\text { and analysis } \\
\text { of morphological } \\
\text { changes } \\
\text { over time }\end{array}$} & $t$ & - & - & $t$ & $t$ & $t$ & \\
\hline $\begin{array}{c}\text { Film } \\
\text { documentation }\end{array}$ & & + & - & - & 나 & H & + & \\
\hline $\begin{array}{c}\text { Method of } \\
\text { benchmarks }\end{array}$ & & t & $t$ & & $+/=$ & 4 & $+/=$ & \\
\hline $\begin{array}{l}\text { 3D terrestrial } \\
\text { laser scanning }\end{array}$ & & 4 & tr & $+/=$ & - & - & + & \\
\hline $\begin{array}{c}\text { Scanning with } \\
\text { structured light LED }\end{array}$ & & + & $t$ & t & - & - & - & $t /=$ \\
\hline $\begin{array}{c}\text { Terrestrial } \\
\text { photogrammetry }\end{array}$ & & $t$ & $t$ & $t$ & t & $t$ & $t$ & t \\
\hline $\begin{array}{c}\text { Aerial } \\
\text { photogrammetry }\end{array}$ & & $t$ & $t$ & $t$ & $t$ & $t$ & + & $t$ \\
\hline $\begin{array}{l}\text { Modelling of } 2.5 \mathrm{D} \\
\text { or } 3 \mathrm{D} \text { objects using } \\
\text { photogrammetry }\end{array}$ & & + & t & t & t & $t$ & $t$ & $t$ \\
\hline
\end{tabular}

a) Data representativeness for concluding about morphological changes occurring within study area: + suitable, +/= medium, = unsuitable

b) Data representativeness for comparative numerical analysis of observed morphological changes: + suitable, +/= medium, = unsuitable

c) Data facilitating clear result to subsequent comparative analysis: + suitable, +/= medium, = unsuitable

d) Work necessary for application of method in the field: + light, +/= medium, = heavy

e) Estimated costs of method involving cost of equipment, employment, software and others: + low, +/= medium, = high

f) Estimated size of study area: + above $100 \mathrm{~m}^{2}+/=$ from $100 \mathrm{~m}^{2}$ to $1 \mathrm{~m}^{2}$, = below $1 \mathrm{~m}^{2}$

g) Minimum number of men necessary for execution of documentation method: + one $+/=$ two or three

control points (GCPs) located at characteristic points at the bottom of the quarry, such as fissures or fractures.

During fieldwork at Dingwall, photographs were taken from a UAV. The shutter was released via an application in a phone connected to the controller. Photographs were taken from a height of $25 \mathrm{~m}$, adjusting the flight altitude to changes in the morphology of the terrain and applying 60-80\% overlap between photographs. Both flight altitude and overlap between photographs were controlled using a dedicated mobile application, DJI GO 4. The application also enabled us to check the following: the location of the UAV on a satellite map, the battery level, GPS positioning, and the connection of the controller with the UAV. It also made it possible to take photographs while regulating parameters such as exposure, shutter speed, and resolution. The flight procedure was preceded by formalities related to obtaining permission for a flight along a visual line of sight (VLOS), issued by Transport Canada. GCPs were measured using a Topcon

Table 2 Equipment used for field documentation employing crucial methods (for additional details, see: Ługowski et al. 2016; Bura and Janowski 2017)

$\begin{array}{ll}\begin{array}{l}\text { Method of } \\ \text { benchmarks }\end{array} & \begin{array}{l}\text { 3D terrestrial laser } \\ \text { scanning }\end{array}\end{array}$

\section{Scanning with structured light LED}

Photogrammetric methods

Aerial photogrammetry Terrestrial Modelling of $2.5 \mathrm{D}$ or photogrammetry 3D objects

\begin{tabular}{|c|c|c|c|}
\hline $\begin{array}{l}\text { D scanner, } \\
\text { antidazzle } \\
\text { cover, laptop, } \\
\text { computer, } \\
\text { power-- } \\
\text { generating } \\
\text { unit, GPS }\end{array}$ & $\begin{array}{l}\text { Unmanned aerial vehicle, } \\
\text { GPS receiver with RTK } \\
\text { corrections, markers } \\
\text { made of PVC, mobile } \\
\text { device with mobile } \\
\text { application }\end{array}$ & $\begin{array}{l}\text { GoPro camera or similar, } \\
\text { GPS receiver with RTK } \\
\text { corrections, markers } \\
\text { made of PVC, mobile } \\
\text { device with mobile } \\
\text { application }\end{array}$ & $\begin{array}{l}\text { Digital single, lens } \\
\text { reflex camera, GPS } \\
\text { receiver with RTK } \\
\text { corrections, markers } \\
\text { made of PVC, level, } \\
\text { compass }\end{array}$ \\
\hline
\end{tabular}


Table 3 Technical data concerning equipment and software used for both aerial and terrestrial photogrammetry. Laboratory work was performed with a personal computer with Windows 10, working with an Intel Core i7-7700K 4.2-GHz central processing unit, 16 GB of random access memory (RAM), and a GeForce GTX 1080 (1835 MHz, $8 \mathrm{~GB})$ graphic card. Both the programme and computer worked faster as a result of the application of a solid-state drive (SSD)

\begin{tabular}{|c|c|c|c|c|c|}
\hline \multirow[b]{2}{*}{$\begin{array}{l}\text { Type of photogrammetric } \\
\text { equipment }\end{array}$} & \multirow{2}{*}{$\begin{array}{l}\text { Aerial photogrammetry } \\
\text { Unmanned aerial vehicle }\end{array}$} & \multicolumn{4}{|l|}{ Terrestrial photogrammetry } \\
\hline & & Digital video camcorder & $\begin{array}{l}\text { Digital single } \\
\text { lens reflex camera }\end{array}$ & & $\begin{array}{l}\text { Mirrorless interchangeable } \\
\text { lens camera }\end{array}$ \\
\hline Producer & SZ DJI Technology Co., Ltd. & GoPro, Inc. & Canon, Inc. & Nikon Corporation & Olympus Corporation \\
\hline Model & Phantom 4 Advanced & Hero 4 Black & 5D EOS Mark 2 & D7100 & PEN Lite E-PL 6 \\
\hline Fixing of camera & Non-detachable, 3-axis gimbal & Fixed & Fixed & Fixed & Fixed \\
\hline Image sensor & 1", CMOS, $24 \mathrm{Mpx}$ & $1 / 2.3^{\prime \prime}, 12 \mathrm{Mpx}$ & $\begin{array}{l}\text { Full frame, CMOS, } \\
12 \mathrm{Mpx}\end{array}$ & $\begin{array}{l}\text { APS-C, CMOS, } \\
24 \mathrm{Mpx}\end{array}$ & 4/3", 16.1 Mpx \\
\hline Focal length & $18 \mathrm{~mm}$ & $3 \mathrm{~mm}$ & $24 \mathrm{~mm}$ & $18 \mathrm{~mm}$ & $25 \mathrm{~mm}$ \\
\hline $\begin{array}{l}\text { Equivalent of full frame } \\
\text { focal length }\end{array}$ & $48.6 \mathrm{~mm}$ & $17 \mathrm{~mm}$ & $24 \mathrm{~mm}$ & $27 \mathrm{~mm}$ & $50 \mathrm{~mm}$ \\
\hline Equivalent type of lens & Standard angle & Ultra-wide angle & Wide angle & Wide angle & Standard angle \\
\hline Shutter release & $\begin{array}{l}\text { Mobile application } \\
\text { DJI GO } 4 \text { or controller }\end{array}$ & $\begin{array}{l}\text { Mobile application } \\
\text { GoPro }\end{array}$ & - & - & - \\
\hline $\begin{array}{l}\text { Estimated work time } \\
\text { with one battery }\end{array}$ & $30 \min$ & $2 \mathrm{~h}$ & $4-5 \mathrm{~h}$ & $4-5 \mathrm{~h}$ & $5-6 \mathrm{~h}$ \\
\hline $\begin{array}{l}\text { Essential software during } \\
\text { laboratory works }\end{array}$ & \multicolumn{5}{|l|}{ Agisoft Photoscan Professional } \\
\hline $\begin{array}{l}\text { Additional software during } \\
\text { laboratory works }\end{array}$ & \multicolumn{5}{|c|}{$\begin{array}{l}\text { ArcGIS, Agisoft Viewer, Core! Graphic X9, X7, RawTherapee 5.4, } \\
\text { Adobe Photoshop, Adobe Reader, Microsoft Excel }\end{array}$} \\
\hline
\end{tabular}

HiPer SR GPS receiver with RTK corrections. Measurements were made at the locations of photogrammetric markers $(45 \times$ $42 \mathrm{~cm}$ ) used as GCPs.

The photographs, along with the collected GCPs, served as the initial resources in the further process of photogrammetric modelling in the Photoscan programme (Table 3). This programme is based on the Structure from Motion (SfM) tool, which locates photographs based on exchangeable image file format (EXIF) data and generates the space of the modelled object (Westoby et al. 2012). SfM is a method of obtaining a three-dimensional structure for physical objects based on overlapping photographs. SfM automatically generates spatial geometry and camera positions and their orientation using the Bundle Adjustment algorithm (Snavely 2008). A detailed description of this algorithm can be found in Triggs et al. (2000).

Map creation in the Photoscan programme proceeded in several stages, in precise accordance with the programme's standard rules (Agisoft 2016). Initially, following the addition

Table 4 Parameters and numerical values characterising the results of photogrammetric work (Agisoft 2016)

\begin{tabular}{|c|c|c|c|c|c|c|}
\hline & \multicolumn{2}{|c|}{ Maps of study area } & \multicolumn{2}{|l|}{ 3D models } & \multicolumn{2}{|l|}{ Microtopography models } \\
\hline & $\begin{array}{l}\text { Pisky } \\
\text { quarry, one } \\
\text { field }\end{array}$ & $\begin{array}{l}\text { Dingwall quarry, five } \\
\text { separated or connected } \\
\text { fields }\end{array}$ & $\begin{array}{l}\text { Pisky quarry, } \\
\text { hydration form } \\
\text { no. } 89\end{array}$ & $\begin{array}{l}\text { Dingwall quarry, } \\
\text { hydration form } \\
\text { no. } 6\end{array}$ & $\begin{array}{l}\text { Pisky quarry, karst } \\
\text { surface on gypsum- an- } \\
\text { hydrite block }\end{array}$ & $\begin{array}{l}\text { Dingwall quarry, karst } \\
\text { surface on hydration } \\
\text { form no. } 5\end{array}$ \\
\hline \multirow[t]{2}{*}{ Time of field works } & 02.09-08.09. & $13.09-24.09$. & $26.07-03.08$ & $13.09-24.09$. & 01.08 & $13.09-24.09$. \\
\hline & 2015 & 2018 & 2016 & 2018 & 2016 & 2018 \\
\hline $\begin{array}{l}\text { Number of images } \\
\text { captured }\end{array}$ & 4388 & 2539 & 133 & 182 & 50 & 74 \\
\hline Area covered & $12,100 \mathrm{~m}^{2}$ & $197,900 \mathrm{~m}^{2}$ & $34 \mathrm{~m}^{2}$ & $195 \mathrm{~m}^{2}$ & $0.22 \mathrm{~m}^{2}$ & $0.24 \mathrm{~m}^{2}$ \\
\hline $\begin{array}{l}\text { Ground sampling } \\
\text { distance of DSM }\end{array}$ & $3.47 \mathrm{~cm}$ & From 1.26 to $2.75 \mathrm{~cm}$ & $2.45 \mathrm{~cm}$ & $2.83 \mathrm{~cm}$ & $0.02 \mathrm{~cm}$ & $0.05 \mathrm{~cm}$ \\
\hline $\begin{array}{l}\text { Ground sampling } \\
\text { distance of } \\
\text { orthophotomap }\end{array}$ & $0.43 \mathrm{~cm}$ & From 0.47 to $0.69 \mathrm{~cm}$ & $0.61 \mathrm{~cm}$ & $0.71 \mathrm{~cm}$ & $0.02 \mathrm{~cm}$ & $0.03 \mathrm{~cm}$ \\
\hline $\begin{array}{l}\text { Amount of points per } \\
\mathrm{cm}^{2}\end{array}$ & 0.08 & From 13 to 63 & 1660 & 1250 & 21,800 & 3400 \\
\hline $\begin{array}{l}\text { Root Square mean } \\
\text { error for ground } \\
\text { control points }\end{array}$ & $17.7 \mathrm{~cm}$ & $\begin{array}{l}\text { From } 1.0 \mathrm{~cm} \text { to } 4.7 \mathrm{~cm} \text {, } \\
\text { and } 27.0 \mathrm{~cm} \text { for one } \\
\text { field }\end{array}$ & $1.2 \mathrm{~cm}$ & $1.5 \mathrm{~cm}$ & - & $1.1 \mathrm{~cm}$ \\
\hline $\begin{array}{l}\text { Amount of ground } \\
\text { control points }\end{array}$ & 6 & From 4 to 7 & 5 & 5 & - & 3 \\
\hline
\end{tabular}


of photos, the programme automatically located the photogrammetric markers within the photographs; the authors exerted control over their valid position. In the case of Pisky, this step was omitted. In the case of Dingwall, the geographic coordinates of the photos taken by UAV were converted in order to display them within the same system of coordinates as the measured GCPs, i.e. the NAD83 MTM 4 coordinate system. Next, the programme performed photo alignment without camera optimisation and created a sparse point cloud; then, a dense point cloud was generated, reflecting the terrain surface more precisely than the sparse point cloud due to a greater number of points. Next, on the basis of the dense point cloud, a mesh, i.e. a so-called surface model, was created from a triangular grid. Due to the very low degree of coverage of the rock by vegetation, the dense point cloud classification was not applied. In the next stage, the texture of the model was created in order to more clearly visualise the actual hydration landscape. Following creation of the mesh with texture, GCPs were marked within the models. In the case of Pisky, this task was carried out manually, but in the case of Dingwall, GCPs were marked in lieu of photogrammetric markers. For each GCP, the assignment of coordinates was accomplished during fieldwork; only these coordinates were used for geographic location of the models. The model at Pisky was created in the WGS 84 coordinate system, the model at Dingwall in NAD83 MTM 4. Models embedded in space served as the basis for the creation of digital elevation models (DSMs) in the Photoscan programme and orthophotomaps. Both the DSMs and the orthophotomaps were saved in the TIFF format, which contains spatial data and thus can be subjected to spatial analysis in the ArcGIS programme (Table 3).

As a result of the use of photogrammetry, DSMs and orthophotomaps were obtained from both sites: at Pisky in the form of a single field, at Dingwall in the form of five separated or connected fields, representing the most important or active anhydrite hydration zones (Fig. 3). The model of the study area at Pisky was characterised by slightly lower accuracy, according to the value of the RMSE (root mean square error) parameter for GCP error (Table 4; Agisoft 2016), than most of the Dingwall models (with the exception of one in the northern part of the central quarry zone, with an RMSE equal to $27.0 \mathrm{~cm}$; Table 4). The greater error at Pisky was presumably caused by the greater number of photographs (taken from the height of $4 \mathrm{~m}$ ) taken in relation to the size of the photographed area (Table 4). For one model at Dingwall, with RMSE equal $27.0 \mathrm{~cm}$, the greater error may have been connected with the excessively linear arrangement of the GCPs.

DSMs and orthophotomaps of the areas at Pisky and Dingwall can be used for many purposes, e.g. to conduct analysis of morphology and the rate of its evolution in time, to conduct structural analysis, to determine the quantitative characteristics of hydration domes and ridges, and to map gypsum-anhydrite rock lithology. ArcGIS, a basic programme
Fig. 4 Morphological evolution and photogrammetric documentation of selected hydration domes: form no. 89 at Pisky in Ukraine (a-e) and form no. 6, the so-called Ramesh Cave at Dingwall in Canada $(\mathbf{f}-\mathbf{j})$. a, b Eight years of development of the cave. c 3D model based on documentation made on 29 July 2016. d, e Cross sections along the III'-III" (d) and IV'IV" (e) lines. f, $\mathbf{g}$ Twelve years of development of the cave. $\mathbf{h}$ 3D model based on documentation made on 13 September 2018. i, j Cross sections along the $\mathrm{V}^{\prime}-\mathrm{V}^{\prime \prime}$ (i) and $\mathrm{VI}^{\prime}-\mathrm{VI}^{\prime \prime}(\mathbf{j})$ lines

containing most of the tools necessary for achieving the above objectives, is characterised primarily by the availability of Spatial Analysis and Raster Analysis tool modules. The basic function of these tools was to obtain hypsometric profiles (Fig. 3e), maps of hillshade (Fig. $3 \mathrm{~b}$ and d), maps representing the degree of surface slope, maps indicating the directions in which physical slopes face, and maps with a curvature function displaying the shape of slopes. Moreover, on the basis of the obtained 2.5D and 3D models, the authors carried out various measurements in the Photoscan and ArcGIS programmes. In the latter, diagrams of features such as fractures, joint systems, and directions of elongated ridges were plotted. The use of DSMs (equivalents of DTMs) enabled the computation of so-called differential models of the surface changes to the elevated rock layer over time. These models can be computed through the subtraction of older rock surfaces from younger ones, which is the function of one of the primary Raster Analysis tools in the ArcGIS programme.

\section{D Models}

Anhydrite hydration relief is characterised by the occurrence of forms ranging from several centimetres to several metres, or sometimes more, in planar extension. The morphological documentation of hydration forms and, above all, hydration caves was extended and supplemented by additional models with lower values of ground sampling distance (GSD; Table 4), close to $0.5 \mathrm{~cm}$. The need to create separate $3 \mathrm{D}$ models results not only from the insufficient value of GSD in the maps and the consequent insufficient accuracy of the topography elements but also from the inability of the UAV camera (due to lack of access) to take photos of the interior of the caves.

The 3D models of anhydrite hydration forms were created using only a camera and a GPS receiver with the application of the Photoscan programme. The photographs were taken from the ground from each side of the object at three different heights. In several cases, when the inner chamber or cave was sufficiently accessible to allow entrance, pictures of internal rock voids were taken in order to model them and integrate them with the external surface.

At Pisky, photographs of selected objects were taken with a digital single-lens reflex camera (DSLR; Tables 2 and 3). At the time the object was photographed, several photogrammetric markers were placed within its range to improve the quality 

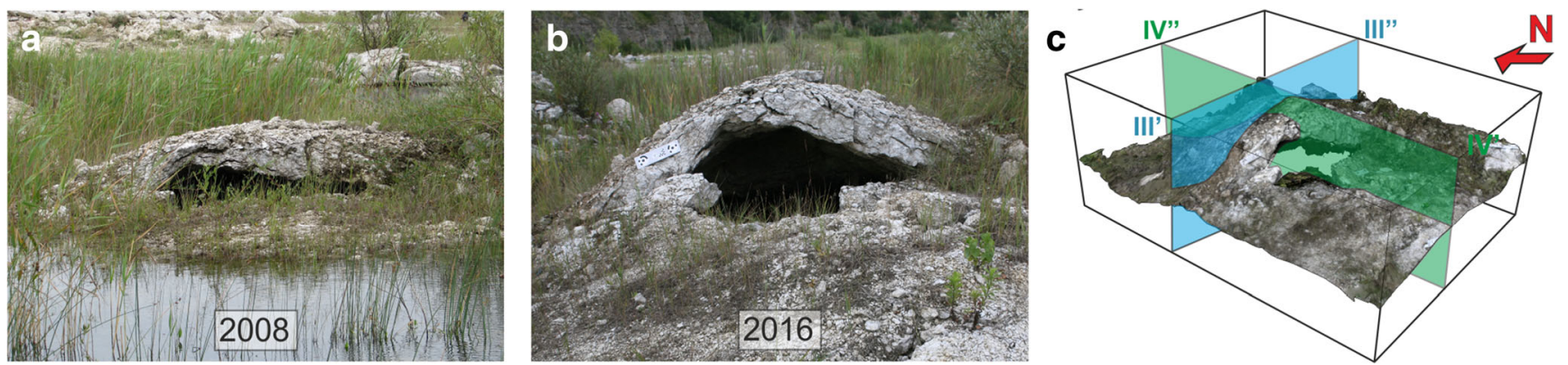

d

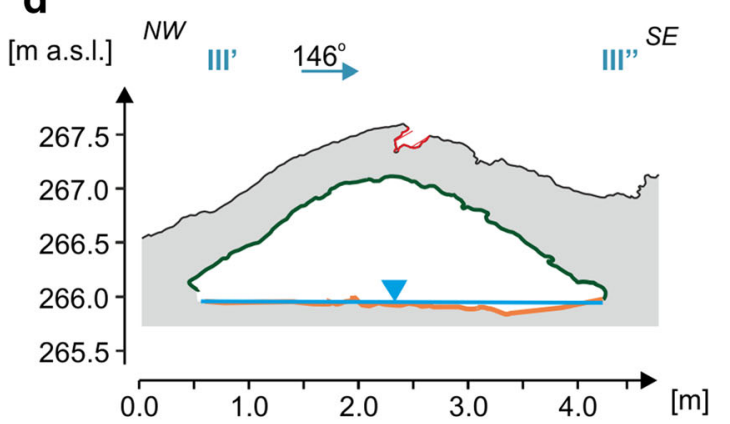

e

[m a.s.I.] SW IV, $\stackrel{53^{\circ}}{\longrightarrow}$

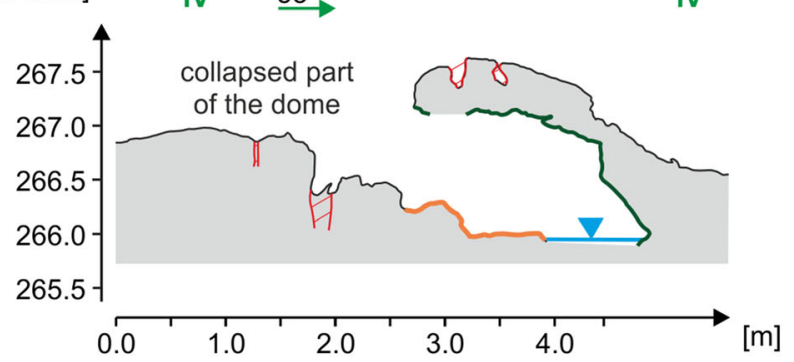

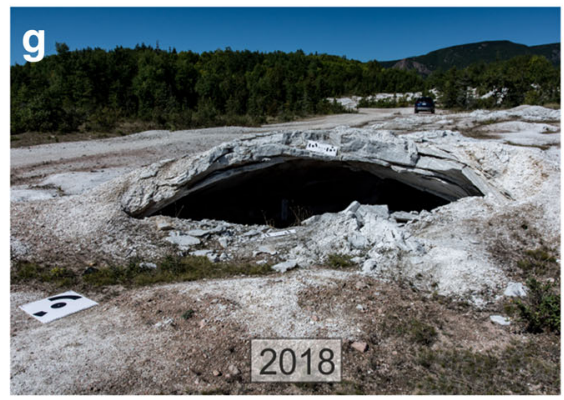

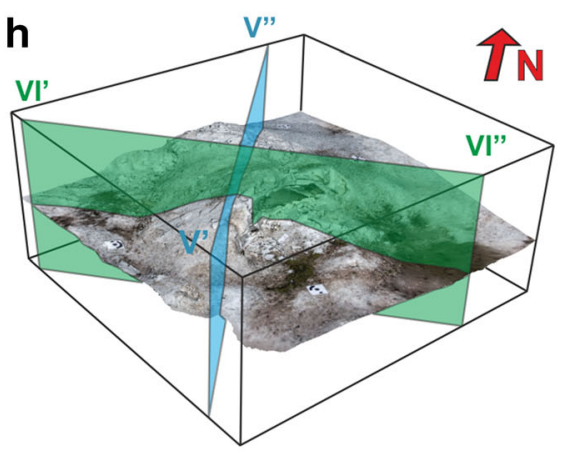

i
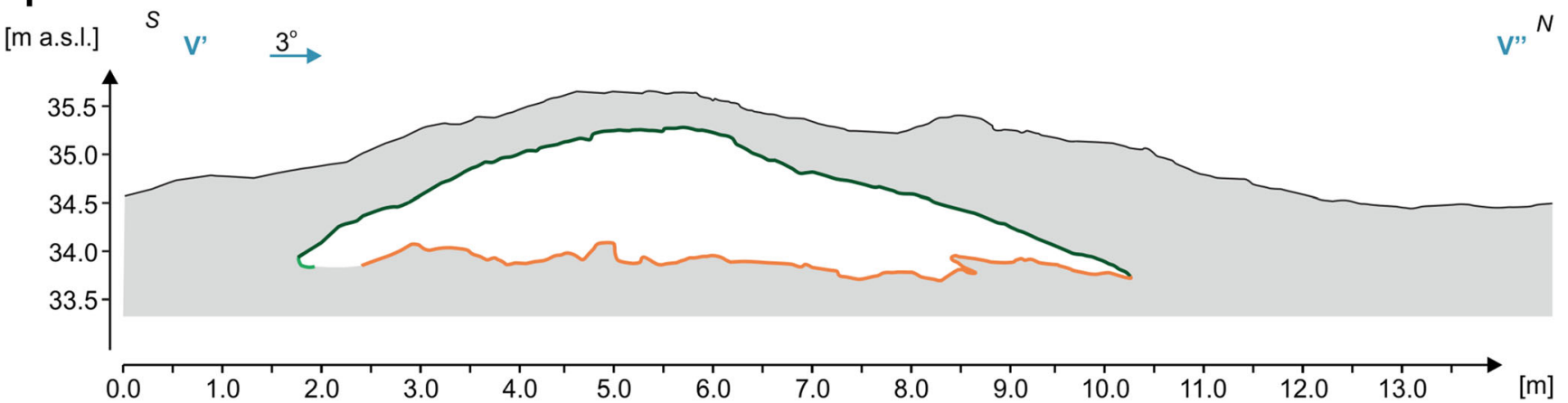

j

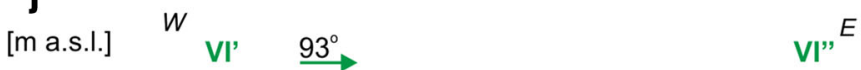

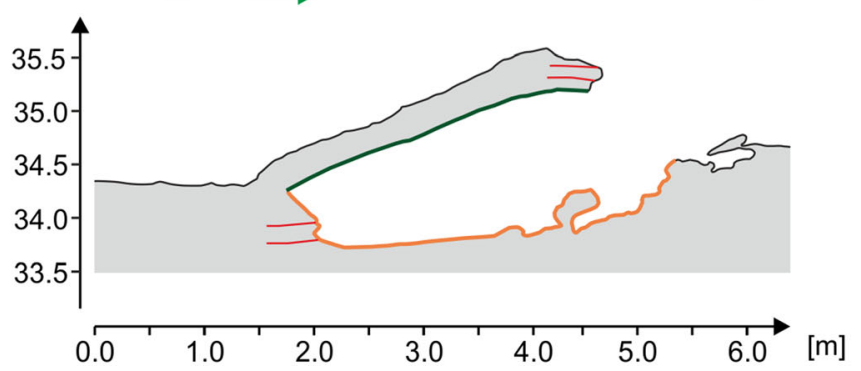

Legend

_ surface of a hydration form

_ roof surface of hydration cave

_ floor surface of hydration cave

$\nabla$ ground water level within form no. 89 on 28 July 2016

H fracture within gypsum-anhydrite rock

$\stackrel{57^{\circ}}{\longrightarrow}$ azimuth of profile 
of the model. GCPs were measured within the photographed objects using the previously mentioned Leica receiver. As in the case of the orthophotomap at Pisky, measurement of GCPs was carried out at characteristic points. In total, 4700 photographs of 28 objects documented as hydration forms were taken at the bottom of the quarry at Pisky. One exemplary form is presented in Fig. $4 \mathrm{a}-\mathrm{e}$.

At Dingwall, the authors used two types of cameras (a DSLR and a mirrorless interchangeable lens camera, or MILC; Table 3). Hydration caves were photographed as at Pisky. GCPs were measured on the surface of hydration forms. Seventeen anhydrite hydration forms were documented in this way; 2700 photographs were made; one form is presented in Fig. $4 \mathrm{f}-\mathrm{j}$.

Computer work using the Photoscan programme was carried out as in the case of the map of the study area at Dingwall. Following their creation, DSMs and orthophotomaps of hydration forms were exported in the TIFF file format for subsequent spatial analysis in the ArcGIS programme. Additionally, 3D models were saved in the PDF file format, which enables threedimensional previews of models in the Adobe Reader programme (Table 3); as well, Adobe Reader tools were used to create cross sections and distance measurements. In order to further describe the internal morphology of the cave, the roofs and floors of caves were separated from the model. This separation was accomplished by means of designation by the user of indicated parts of the dense point cloud. This operation enabled the creation of separate DSMs and orthophotomaps of the roofs and floors of the caves, which were then analysed in the ArcGIS programme.

As a result of photographic work, documentation of several dozen hydration forms was obtained in the form of both 3D and 2.5D models. Based on these models, DSMs and orthophotomaps of the hydration forms were obtained. Both $3 \mathrm{D}$ and $2.5 \mathrm{D}$ models were characterised by very high accuracy of data mapping, according to the value of the RMSE parameter (Table 4).

The method of analysis of particular 2.5D models of hydration forms coincides with the method of spatial analysis of the study area maps, particularly in reference to the creation of shaded relief. In the analysis of $3 \mathrm{D}$ models including such morphological elements as interiors of caves and rock shelters, a larger set of the spatial and raster analytical tools of the ArcGIS programme was used. These tools included the generation of cross sections (Fig. 4) and measurements of distances (e.g. thickness of the elevated rock layer), angles, areas, and volumes. Application of these tools supported analysis of cave growth, structural analysis within hydration forms, macroscopic description of rock, and analysis of distances between benchmarks.
Fig. 5 Photogrammetric documentation of karst relief on the gypsumanhydrite block at Pisky in Ukraine with mounted benchmarks (blue circles) (a-e), and on the slope of hydration form no. 5 at Dingwall in Canada $(\mathbf{f}-\mathbf{j})$. a Weathered gypsum-anhydrite block with solution flutes on the surface. b 3D model of part of the block. $\mathbf{c}$ Part of the 3D model. d DSM of the block. e Hypsometric profiles along the VII'-VII" and VIII'VIII" lines. f Hydration form with a marked fragment of the rock slope where the karst relief was documented. $\mathbf{g} 3 \mathrm{D}$ model of part of the slope. $\mathbf{h}$ Part of the 3D model. i DSM of the rock slope. $\mathbf{j}$ Hypsometric profiles along the $\mathrm{IX}^{\prime}-\mathrm{IX}^{\prime \prime}$ and $\mathrm{X}^{\prime}-\mathrm{X}^{\prime \prime}$ lines

\section{Microtopography Documentation}

The relief of the studied areas contains a wealth of small-scale and micromorphological forms, ranging from a few millimetres to ca $50 \mathrm{~cm}$. This relief is the effect not only of transition of anhydrite into gypsum but also of karst dissolution, particularly of the bare surface of gypsum-anhydrite rocks. Dissolution leads to the creation of various karren forms that require more detailed documentation via terrestrial photogrammetry with a GSD below or near $0.05 \mathrm{~cm}$.

The methodology of microtopography documentation using photogrammetry was nearly the same as described above. The only difference was related to the coordinate system, concerning a situation where it was impossible to measure the location of GCPs with RTK corrections within the photographed object. This situation required the use of a local coordinate system for a model that followed the placement of several photogrammetric markers within the object. However, this time, the markers served not only as model building support and scale bars but also as a way to preserve north directional and horizontal lines.

Two exemplary models are presented in Fig. 5. The first shows a surface covered with karren at Pisky (Fig. 5a-e), while the second documents a fragment of the karstified slope of the hydration dome at Dingwall (Fig. 5f-j). The RMSE of the second model indicates the very high accuracy of the resulted model (Table 4). Due to the lack of measured GCPs and the use of the local coordinate system, no RMSE could be calculated in the first case.

Exemplary 3D models of microtopography from Dingwall and Pisky faithfully reproduce very small fragments of relief of the gypsum-anhydrite surface. DSMs enable the generation of hypsometric profiles perpendicular to solution flutes (Fig. 5e and $\mathrm{j}$ ). Measuring the shape of solution flutes now and in future will enable estimation of the rate of dissolution of the rock. However, one visible disadvantage of karst relief modelling is its inaccurate display of sharp edges present on documented karren forms, which are absent on hypsometric profiles.

\section{Conclusions}

Photogrammetry turned out to be the best method for documentation of the anhydrite hydration zones at Dingwall and 

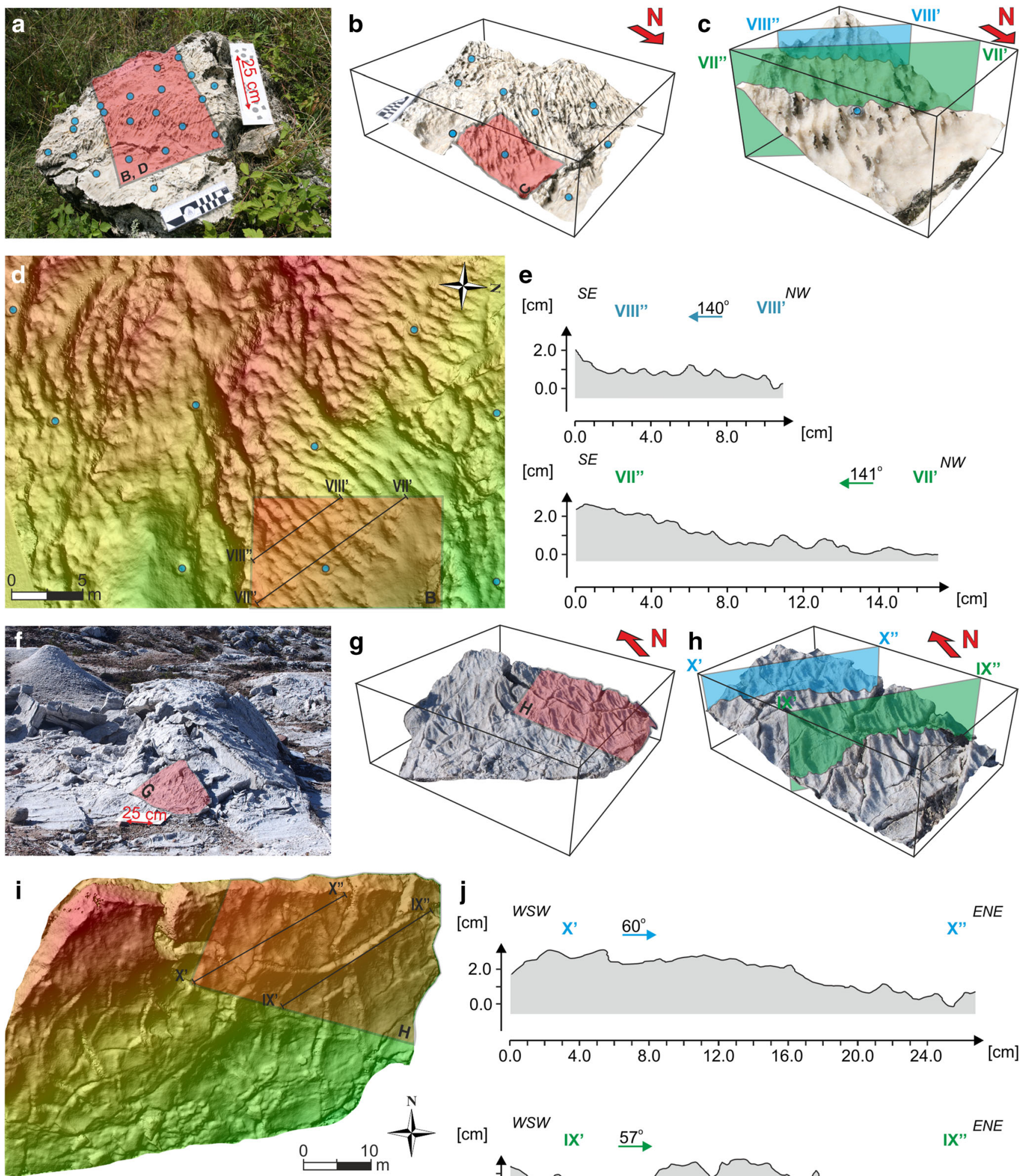

Legend

B area shown on the $B$ picture - benchmark I' l' a line of hypsometric profile $\stackrel{57^{\circ}}{\longrightarrow}$ azimuth of profile

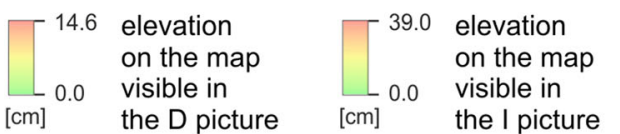

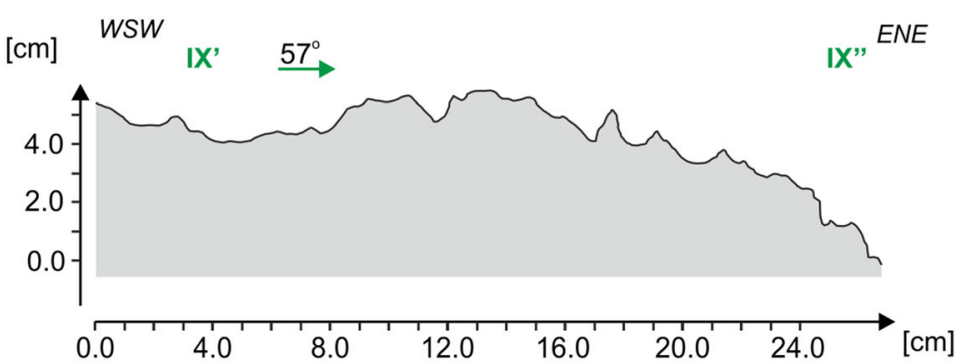


Pisky. The creation of maps of study areas yielded the intended results in contrast to the methods of terrestrial laser scanning used previously at Pisky (Lugowski et al. 2016). The obtained maps are characterised by GSD values ranging from 1.26 to $3.47 \mathrm{~cm}$, a very high level of accuracy of relief mapping in the case of Dingwall, and an acceptably high level of accuracy in the case of Pisky (Table 4). The efficiency of this method is related to the short time necessary to create a single model of either a large or a small area. For example, for an area of $150 \times 400 \mathrm{~m}$, fieldwork with the UAV took about $3 \mathrm{~h}$, computer work $6 \mathrm{~h}$. However, it should be noted that where rocks are covered with rich vegetation, as in the case of the Walkenried area, the photogrammetry method will not be able to create a map of a whole field. In such a case, it is necessary to use an UAV with a lidar scanner (Sankey et al. 2017).

Aerial photogrammetry with the use of a UAV is a suitable method for obtaining data on the examined areas. Photographs enabled the creation of a DSM and orthophotomap of the area. In addition, the use of UAVs has great potential for promotion of the studied sites, showing their natural value through the sharing of photographs, 3D models, orthophotomaps, or films on a website (http://hydrationcaves.com), Facebook (https://www.facebook.com/hydrationcaves/), Youtube (https://youtu.be/SpfK5khUR7Y) or Instagram (https://www. instagram.com/hydrationcaves/). The same applies to the data obtained via terrestrial photogrammetry, where it is also possible to publish photographs, 3D models, and orthophotomaps.

Photogrammetric 3D models of hydration and karst forms showed a very high level of accuracy and required a relatively short work period for their preparation. One researcher is able to make one 3D model during a period from 5 to $10 \mathrm{~h}$ (collecting pictures and GCPs in the field and modelling in a computer programme within this time). In cases where it was not possible to accurately measure GCPs in order to locate the model in geographical space, we were able to document our model using the local coordinate system. A researcher can create excellent documentation of landform objects up to several metres in height, width, and length using only a camera, photogrammetric markers, a compass, and a tape measure.

\section{Summary}

The sites with anhydrite hydration caves in Pisky, Dingwall, and the Alebastrovyye Islands are potential geosites and geomorphosites requiring protection similar to that provided at Walkenried. It is obvious that it is only as protected objects that hydration caves can properly play an educational role and serve as tourist attractions in the future. More importantly, protection is the only way to preserve these fragile forms from destruction due to improper human activity and thereby to permit continuing studies.
Documentation of anhydrite hydration zones and their morphology (which is subject to rapid and irreversible changes over time) was accomplished using photogrammetry. Both terrestrial (using a camera) and aerial (using an UAV) photogrammetry were employed. Photogrammetry possessed relevant advantages in the documentation of study areas compared with other methods applied by the authors: the high level of accuracy of the data thus acquired was attributable to GSD value, the quality of the models, the rate of application of the methods, and their capacity for the rapid creation of DSMs and orthophotomaps. In Dingwall and Pisky quarry, the authors successfully created photogrammetric models of the morphology of separate hydration forms and of karst karren relief. These models were subjected to quantitative geomorphological analyses, with positive results.

The authors strongly recommend the method of photogrammetry as the most efficient method, in terms of costs, workload, and effects, to be used in the documentation of the morphology of rocky surfaces.

Acknowledgements The equipment for the GPS measurement of GCPs at Pisky was provided by Janusz Janowski and Marta Bura from 3D Scanners Studio at the Institute of Archaeology, University of Warsaw. The authors would like to thank all those who participated in our research at Pisky, Walkenried, and Dingwall. Special thanks to the following persons, particularly for their help in the field: Andriy Bermes, Valdemaras Degulis, Barbara Kremer, Grzegorz Przybylik, and Olena Tomeniuk. We thank Mr. Gary Burchell for his kind permission to undertake our investigation with the 'drone' at Dingwall. We are very grateful to Mrs. Janet Connor and Mr. John Connor for their help in the course of the expedition in Dingwall. We also thank two anonymous reviewers for critical comments which helped to improve the present paper.

Funding information This research was sponsored by National Science Centre, Poland, grant no. DEC-2012/05/B/ST10/00918, and financed using Polish budget funds for science in 2017-2020 as a research project within the 'Diamond Grant' programme, grant no. 0002/DIA/2017/46.

Open Access This article is licensed under a Creative Commons Attribution 4.0 International License, which permits use, sharing, adaptation, distribution and reproduction in any medium or format, as long as you give appropriate credit to the original author(s) and the source, provide a link to the Creative Commons licence, and indicate if changes were made. The images or other third party material in this article are included in the article's Creative Commons licence, unless indicated otherwise in a credit line to the material. If material is not included in the article's Creative Commons licence and your intended use is not permitted by statutory regulation or exceeds the permitted use, you will need to obtain permission directly from the copyright holder. To view a copy of this licence, visit http://creativecommons.org/licenses/by/4.0/.

\section{References}

Adams GC (1991) Gypsum and anhydrite resources in Nova Scotia. Economic Geology Series 91-1. Department of Natural Resources. Halifax. Nova Scotia:1-293 
Agisoft (2016) Agisoft PhotoScan user manual professional edition, version 1.2. Agisoft LLC, St Petersburg, pp 1-97

Alonso EE, Berdugo IR, Ramon A (2013) Extreme expansive phenomena in anhydritic-gypsiferous claystone: the case of Lilla tunnel. Géotechnique 63:584-612

Bąbel M, Bogucki A, Jacyszyn A (2007) Gypsum domes and weathering gypsum crusts in the karst relief of western Ukraine. Prace Instytutu Geografii Akademii Świętokrzyskiej w Kielcach 16:59-70 (In Polish with English summary)

Bąbel M, Bogucki A, Jacyszyn A, Ługowski D, Olszewska-Nejbert D, Nejbert K, Jarzyna A, Bermes A, Przybylik G, Tomeniuk O (2017a) Weathering anhydrites at Pisky quarry. Part I. General characteristics. In: Bąbel M, Olszewska-Nejbert D, Nejbert K, Kotowski J (eds) Wietrzenie skał gipsowych i anhydrytowych. Polsko-Ukraińskie Seminarium Naukowe, 19-21.01.2017, Warszawa - Wydzial Geologii Uniwersytetu Warszawskiego. IGP WG UW, Warszawa, pp 18-22 (In Polish)

Bąbel M, Yatsyshyn A, Bogucki A, Jarzyna A, Ługowski D, OlszewskaNejbert D, Nejbert K, Kotowski J, Przybylik G, Bermes A, Tomeniuk O, Mik I, Mik V (2017b) Development of the unique landforms in the zone of weathering gypsum-anhydrite rocks at Pisky (Shchyrka river valley, Dnister basin). In: Skilsky IV, Vikyrchak O (eds) Scientific principles of conservation management of ecosystems in the Dnister Canyon area. Proceedings of the Second International Scientific and Practical Conference dedicated to the 170th anniversary of publication of Rudolf Kner's work which marked the beginning of the profound paleontological investigations in the Dniester canyon, 14-15 September 2017, Zalishchyky, Ternopil region, Ukraine. Druk Art, Chernivtsi, pp 23-25

Beales FW, Oldershaw AE (1969) Evaporite-solution brecciation and Devonian carbonate reservoir porosity in Western Canada. Am Assoc Pet Geol Bull 53(3):503-512

Behrens GH (1703) Hercynia Curiosa, oder Curiöser Hartz-Wald. Verlegts Carl Chriftian Neuenhahn, Nordhausen, pp 1-216

Biese W (1931) Über Höhlenbildung, Teil 1. Entstehung der Gipshöhlen am südlichen Harzrand und am Kyffhäuser. Abhandlungen der Preußischen Geologischen Landesanstalt, Neue Folge 137:1-71. Berlin

Bögli A (1980) Karst hydrology and physical speleology (translated by J.C. Schmid from German edition, Springer 1978). Springer, Berlin, pp $1-270$

Bogucki A, Tomeniuk O (2016) Polish-Ukrainian Seminar "Weathering of gypsum and anhydrite rocks". Visnyk of the Lviv University, Series Geography 50:427-429 (in Ukrainian)

Brilha J (2018) Geoheritage: inventories and evaluation. In: Reynard E, Brilha J (eds) Geoheritage: assessment, protection, and management. Elsevier, Amsterdam, pp 69-85

Bura M, Janowski J (2017) Virtual trip to the hydration caves at Pisky near Lviv (results of 3D documentation using a terrestrial laser scanning; TLS). In: Babel M, Olszewska-Nejbert D, Nejbert N, Kotowski J (eds) Wietrzenie skał gipsowych i anhydrytowych. Polsko-Ukraińskie Seminarium Naukowe, 19-21.01.2017, Warszawa - Wydział Geologii Uniwersytetu Warszawskiego. IGP WG UW, Warszawa, pp 47-51 (In Polish)

Butscher C, Mutschler T, Blum P (2016) Swelling of clay-sulfate rocks: a review of processes and controls. Rock Mech Rock Eng 49:1533-1549

Calaforra JM, Pulido-Bosch A (1999) Genesis and evolution of gypsum tumuli. Earth Surf Process Landf 24:919-930

de Leeuw A, Tulbure M, Kuiper KF, Melinte-Dobrinescu MC, Stoica M, Krijgsman W (2018) New ${ }^{40} \mathrm{Ar} /{ }^{39} \mathrm{Ar}$, magnetostratigraphic and biostratigraphic constraints on the termination of the Badenian salinity crisis: indications for tectonic improvement of basin interconnectivity in Southern Europe. Glob Planet Chang 169:1-15
Fleuchaus P, Blum P (2017) Damage event analysis of vertical ground source heat pump systems in Germany. Geothermal Energy, v.5: article no. 10

Ford DC, Williams PW (2007) Karst hydrogeology and geomorphology. Wiley, Chichester, pp 1-562

Kes AS (1961) Gypsum domes in a desert. Priroda, No. 2:114-115 (In Russian)

Kraus EH (1905) Hydration caves. Science, New Series 22(564): 502-503

Ługowski D, Jarzyna A, Bąbel M, Nejbert K (2016) Data collecting methods used in the field study of weathering anhydrites at Pisky near Lviv. Biuletyn Państwowego Instytutu Geologicznego 466: 201-214 (In Polish with English summary)

MacNeil LA, Pufahl PK, James NP (2018) Deposition of a saline giant in the Mississippian Windsor group, Nova Scotia, and the nascent late Paleozoic ice age. Sediment Geol 363:118-135

Moore RG, Ryan RJ (1976) Guide to the invertebrate fauna of the Windsor Group in Atlantic Canada. Province of Nova Scotia, Department of Mines, Nova Scotia, Canada 67-5:1-57

Reimann M (1991) Geologisch-lagerstättenkundliche und mineralogische Untersuchungen zur Vergipsung und Volumenzunahme der Anhydrite verschiedener geologischer Formationen unter natürlichen und labormäßigen Bedingungen. Geologisches Jahrbuch, Reihe D 97:21-125

Reimann M, Vladi F (2003) Zur Entwicklung der sog. Zwergenkirche am Sachsenstein. bei Walkenried, Landkreis Osterode am Harz, Niedersachsen und vergleichende Beobachtungen zur rezenten Entstehung von Quellungshöhlen in einem aufgelassenen Gipssteinbruch bei Dingwall, Nova Scotia, Kanada. Mitteilungen des Verbandes deutscher Höhlen- und Karstforscher 49(3):75-77

Reinboth F (1997) Die Zwerglöcher bei Walkenried am Südharz Bemerkungen zur Frage der Quellungshöhlen. Die Höhle, Zeitschrift für Karst- und Höhlenkunde 48(1):1-13

Reynard E (2009) Geomorphosites: definitions and characteristics. In: Reynard E, Coratza P, Regolini-Bissig G (eds) Geomorphosites. Verlag Dr. Friedrich Pfeil, München, pp 9-20

Sankey T, Donager J, McVay J, Sankey JB (2017) UAV lidar and hyperspectral fusion for forest monitoring in the southwestern USA. Remote Sens Environ 195:30-43

Snavely KN (2008) Scene reconstruction and visualization from Internet photo collections. $\mathrm{PhD}$ thesis. University of Washington, Seattle, pp $1-192$

Stenson RE (1990) The morphometry and spatial distribution of surface depressions in gypsum, with examples from Nova Scotia, Newfoundland and Manitoba. MSc thesis, McMaster University, Hamilton, Canada, pp 1-134

Stenson RE, Ford DC (1993) Rillenkarren on gypsum in Nova Scotia. Géog Phys Quatern 47(2):239-243

Stolberg F (1926) Die Höhlen des Harzes, Bd. 1. Einleitung und Südharzer Zechsteinhöhlen. Sonderausgabe der illustrierten Monatsschrift "Der Harz", Heft 2. Eilers-Verlag G.m.b.H., Magdeburg: $1-40$

Triggs B, Mclauchlan P, Hartley R, Fitzgibbon A (2000) Bundle adjustment - a modern synthesis. In: Triggs B, Zisserman A, Szeliski R (eds) Vision algorithms: theory and practice. IWVA 1999, Lecture Notes in Computer Science, vol 1883. Springer, Berlin, Heidelberg, pp 1-71

Westoby MJ, Brasington J, Glasser NF, Hambrey MJ, Reynolds JM (2012) 'Structure-from-motion' photogrammetry: a low-cost, effective tool for geoscience applications. Geomorphology 179:300-314

Yushkin NP (1994) Supergenesis of Carboniferous anhydrites of Novaya Zemlya. Polar Geogr Geol 18(1):33-43

Zanbak C, Arthur RC (1986) Geochemical and engineering aspects of anhydrite/gypsum phase transitions. Bull Assoc Eng Geol 23(4): $419-433$ 